\title{
( 5$)$
}

11. A curious Fact in the Natural Hiffory of the Common Mole, Talpa europæa, Linn. By Artbur Bruce, Efq. Secretary to the Natural. Hijfory Society of Edinburgh.

\section{Read FIne 2, 1793.}

THAT the mole does, in common with other quadrupeds and 1 man, poffefs that fpirit of curiofity which prompts to emigration and even to tranfmarine expeditions, I found out laft fummer from the beft authenticated facts.

In vifiting the Loch of Clunie, which I often did, I obferved in it a fmall inland at the diftance of 180 yards from the neareft land, meafured to be fo upon the ice. Upon the inland, Lord Airly, the proprietor, has a caftle and fmall thrubbery. I obferved frequently the appearance of freh mole-cafts, or hills. I for fome time took it to be the water-moufe, and one day afked the gardener if it was fo? No, he faid, it was the mole; and that he had caught one or two lately. But that five or fix years ago he had caught two in traps; and for two years after this he had obferved none. But about four years ago, coming afhore in a fummer's evening in the dufk, the $4^{\text {th }}$ or $5^{\text {th }}$ of June, 1o o' clock P. M. he and another refpectable perfon, Lord Airly's butler, faw at. a fmall diftance upon the fmooth water fome animal paddling to, and not far diftant from the ifland. They foon, too foon! clofed with this feeble paffenger, and found it to be our common mole, led by a moft 
6 Mr. BRUCE's curious FaEt concerning the common Mole.

aftonihing inftinet from the neareft point of land (the caftle hill) to take poffeffion of this defert inland. It was at this time for about the fpace of two years quite free from any fubterraneous inhabitant; but the mole has for more than a year paft made its appearance again, and its operations I was witnefs to.

In the hiftory of this animal I do not at prefent recollect any fact fo ftriking; efpecially when we confider the great depth of the water, both in fummer and winter-from fix to ten, fifteen, and fome places as deep as thirty or forty feet, all round the inand.

\section{Edinburgh,}

April 26, 1793. 